DIGITAL COMMONS
@ UNIVERSITY OF SOUTH FLORIDA

Volume 7

Issue 1 Volume 7.1 (Spring 2017)

\section{ABO: Interactive Journal for Women in the Arts, 1640-1830}

\title{
Review of III Composed: Sickness, Gender, and Belief in Early Modern England
}

Amy Mallory-Kani

Mississippi State University, am3466@msstate.edu

Follow this and additional works at: https://digitalcommons.usf.edu/abo

Part of the Dramatic Literature, Criticism and Theory Commons, Educational Methods Commons, Feminist, Gender, and Sexuality Studies Commons, and the Literature in English, British Isles Commons

\section{Recommended Citation}

Mallory-Kani, Amy (2017) "Review of III Composed: Sickness, Gender, and Belief in Early Modern England," ABO: Interactive Journal for Women in the Arts, 1640-1830: Vol.7: Iss.1, Article 4.

http://doi.org/10.5038/2157-7129.7.1.1154

Available at: https://digitalcommons.usf.edu/abo/vol7/iss1/4

This Reviews is brought to you for free and open access by Digital Commons @ University of South Florida. It has been accepted for inclusion in ABO: Interactive Journal for Women in the Arts, 1640-1830 by an authorized administrator of Digital Commons @ University of South Florida. For more information, please contact digitalcommons@usf.edu. 


\section{Review of III Composed: Sickness, Gender, and Belief in Early Modern England}

\section{Keywords}

sickness, gender, belief, religion, patient, medicine, early modern

Creative Commons License

(c) (i) $\ominus$

This work is licensed under a Creative Commons Attribution-No Derivative Works 3.0 License. 
Olivia Weisser. Ill Composed: Sickness, Gender, and Belief in Early Modern England. Yale UP, 2015. ix + 281pp. Index. ISBN: 9780300200706.

Early on in her book, Ill Composed, Olivia Weisser recounts a particularly telling story about a seventeenth-century patient who, in order to get well, is willing toquite literally - take things into his own hands. Hugh Ryder, the practitioner administering the patient's care, decides that "nothing could be done" about the "painful fistulas" in his patient's legs (19). Convinced that amputation is the only viable cure, the patient asserts that "[h]e knew he should be well, if [Ryder] would cut off his Thigh; and that if [Ryder] would lend him a Knife, he would cut it off himself' (19). Weisser's book is full of similarly fascinating instances that emphasize the relative autonomy of patients in the early modern period; in an era in which the medical market included both licensed and unlicensed practitioners and in which knowledge about health and disease was ultimately shared by both practitioners and patients, medical authority was much more fluid than it was in later periods. As Weisser notes in her introduction, the medical landscape began to change dramatically around the turn of the nineteenth century. In some respects, this is certainly true: the passage of legislation like the Apothecaries Act (1815) helped to solidify medicine as an institution, one whose practitioners were highly skilled and extremely knowledgeable about the burgeoning sciences of physiology and epidemiology. These structural changes in the corporate hierarchies of medical practice were complemented by innovations in scientific experimentation; together, these developments contributed to a medical elitism that displaced patient autonomy, since those receiving medical care no longer knew just as much, if not more, about their bodies than the practitioners. However, ideas about bodily humors and the regulation of the non-naturals - described in the book's first chapter-did not disappear when medicine became more institutionalized. Indeed, Weisser's study allows those of us working in later periods to see more fully the continuities between conceptions of illness in the early modern and the modern periods by engaging with concepts - such as gender and belief - that ultimately cut across period boundaries.

Throughout the book, Weisser excels at showing just how important the aforementioned concepts were to individuals' perceptions of illness. By focusing on the written accounts of patients, as well as some practitioners, she demonstrates how the experience of sickness was shaped, both consciously and unconsciously, by language. In other words, early modern patient narratives are mediated through a complex system of interrelated societal markers that, in addition to gender and religious orientation, include class and even location. Weisser breaks new ground by considering these markers from the patients' perspectives. Although the first chapter does not necessarily offer new information on humoral medicine, it reads this tradition from a different perspective. The early parts of the book thus do an 
excellent job of providing the background for the compelling readings of patient narratives (both those written by patients and those that feature in medical texts) that occupy the middle chapters. In particular, Chapter Two, "Learning How to Be Ill," provides superb analyses of a range of life-writings by women, but also men, that engage with the three modalities of the book's subtitle. Through extensive archival research, Weisser concludes that "patients made their observations [about their illnesses] in gendered ways" (48). Significantly, she claims that, although illness narratives written by men regularly drew on the writers' past experiences with illness, women tended to compare their illnesses to others' or to biblical precedents. As a result, there is a "scarcity of . . . self-assessments in women's writing," despite the vehicles - primarily diaries - through which the information is imparted (48). Weisser sets out to prove this through a number of fruitful examples, such as the story of Mary Rich, the Countess of Warwick (1624-78).

In one of the most astute readings in a chapter full of captivating accounts, Weisser focuses on a series of headaches experienced by Rich and recorded in Rich's extensive journals. Rich, a pious woman who practiced daily devotions and prayers, recounts that during the spell of headaches, she felt unable to "poure out [her] soule in prayer to God" (69). Because private devotion in this period required a certain somatic and affective attunement to the divine, the Countess's illness temporarily disables her from attaining this state of spiritual openness, one that is truly embodied by the penitent. As Weisser avers, "The impact of her ailing body on her devotional practices shaped Rich's perceptions of ill health" (70). What is so striking about Weisser's interpretation is her ability to bring the account full circle by reiterating how gender not only shapes the framework of Rich's perceptions - she uses a reflection upon of another's illness (Lady Manchester's) to form her own - but also how it intersects with spirituality and sickness beyond Rich's text. As she explains, the very devotional practices that are disrupted by Rich's illness are also thoroughly gendered. While the "open" and "warm" bodily frame needed to commune with God fit well with perceived ideas about women's frailty and docility, affective and somatic forms of devotion "could threaten important manly markers of bodily control and self-mastery" (71). Through this complex argument, Weisser shows just how entwined sickness, gender, and belief were during the early modern period. In fact, one of the particular strengths of the book is Weisser's ability to hold this dynamic matrix of influence together while simultaneously examining each idea singularly via well-chosen examples.

The middle sections of Ill Composed walk the reader through a set of key readings of pain and suffering, both emotional and physical. In Chapter Three, which focuses on emotional sources of illness, Weisser lobbies forth a number of examples to show how "emotional responses" to various "social stimuli" (including the death of a loved one or one's slide into debt) "sparked a series of internal mechanisms that resulted in illness" (82). Early modern patients perceived 
emotions as "passions" that could often manifest themselves in extreme physical debilities; yet, how much one could feel in any given situation was determined by one's gender. While men could bemoan financial dependency and take to their beds because of it, "manly virtue" disabled them from allowing grief to overcome them physically. Moreover, the way that men expressed emotional illness was markedly different than the way that women imagined emotional symptoms. As Weisser shows, men often focused on the underlying physical processes that made emotions so overpowering, whereas women "emphasized ... the deleterious effects of interpersonal relationships and described instant physical reactions to social disturbances" (103). Although this chapter is not as well-developed as the other main sections of the book (for instance, the author could have briefly explored the relationship between the "passions" and the burgeoning discourses of sentimentality), it nonetheless contributes another important element to Weisser's argument.

The next two chapters, on physical pain and suffering, add surprising twists to the book's approach thus far. If the previous chapters explore how perceptions of illness generally complement, or fall in line with, existing societal views about gender, Weisser's analyses of physical discomfort illustrate how extreme instances of often traumatic pain pushed women to shed their typical silence and meekness in order to cry out via the stirring accounts of their illnesses. What is more, the "manly virtue," mentioned above, that scripted men's reactions to more common forms of sickness, was regularly eschewed when pain and suffering became acute. Ultimately, "common concerns emerge across multiple lives" that contributed to the defiance of "normative gendered behavior" (158). For example, Lady Francis Clifton, writing in 1678, described the excessive pains that she was feeling in language that mimicked the excruciating misery of her experience: "I can hardly gasp, or moove, or stirr my selfe the least in my bed ... without excessive torment" (151). Likewise, Samuel Crew complained of a pain in his legs "as hard as any Iron Wedg" and a pounding sound in his ears that felt like a "Red-hot Iron had been run into them" (137). In both instances, these sufferers struggled to adequately describe the pain and suffering that they endured. Weisser contends that this "struggl[e] with language" allows us to glimpse "how seventeenth-century individuals understood and perceived their bodies" (158). Extreme descriptions of illness thus provide us with access to an aspect of early modern subjectivity that is often beyond our grasp: the emotional effects of physical trauma on selfhood.

The "bodies" on which Weisser focuses in the earlier chapters are all conditioned by their elevated social positions; the records that she references exist largely because their authors were literate and had more consistent access to professional medical care and forms of knowledge. In the last major chapter of Ill Composed, Weisser turns to narratives of the poor to broaden her overall discussions of sickness, gender, and belief in early modernity. Relying on petitions 
for parish relief as examples of how the often illiterate poor sought medical aid, Weisser demonstrates that although there is some overlap between the ways in which different social classes imagined illness, the narratives of the poor ultimately differ from those of other classes in striking ways. For instance, both rich and poor relied on social networks comprised of friends, families, and neighbors to garner medical advice. However, the terms in which the poor defined their illnesses are distinct from those used by wealthier patients. Because many of the individuals seeking parish relief used their bodies for labor, the poor often combined morality and industry to demonstrate how much they deserved aid. What is more, "[m]ost petitioners did not cite a specific disorder" in their applications and they rarely invoked "any of the six non-natural causes of illnesses" to explain their conditions $(172,170)$. Weisser concludes that "economic circumstances" often drove "the sick poor" to seek parish relief and, as a result, "the poor defined suffering in terms of incapacity rather than piety" (178).

In her early discussion of Lady Rich's diary, Weisser cites Rich's reaction to Lady Manchester's loss of her ability to speak: "[M]y uoyce might be taken from me, and therefore it was good for me to make use of it whilst I had it to cry for mersy" (49). This quote is an apt example not only because of what it reveals about the interconnections among gender, sickness, and belief, but also because it neatly encapsulates one of the major aims of Ill Composed: to rescue the voices of early modern patients from obscurity. Weisser certainly succeeds at this task; indeed, she offers an illuminating look at patients' perceptions of illness during a period in which medical authority was much more diffuse. With its careful readings of archival materials, well-chosen illustrations, and clear, accessible, jargon-free style, this book would appeal to both scholars and students of early modern history and to knowledgeable general readers seeking an introduction to medicine in the early modern period. 